\title{
Su kefiri mikroorganizmaları ile fermente edilen portakal suyunda Escherichia coli inaktivasyonunun matematiksel modellemesi
}

\author{
Selin KALKAN ${ }^{1 *}$ \\ ${ }^{1}$ Giresun Üniversitesi, Mühendislik Fakültesi, Gıda Mühendisliği Bölümü, Giresun, Türkiye
}

Geliș Tarihi: 31.10 .2019

"Sorumlu Yazar: selin.kalkan@giresun.edu.tr

Kabul Tarihi: 02.12 .2019

\section{$\ddot{O} \mathbf{z}$}

Su kefiri, farklı taze ve kuru meyvelerden elde edilen, sakkaroz bazlı ev yapımı fermente bir içecektir. Su kefiri taneleri ile hazırlanan bu içecekte baskın florayı laktik asit bakterileri ile bazı maya türleri oluşturmaktadır. Bu çalışmada, su kefiri taneleri ile fermente edilen portakal suyuna inoküle edilen E.coli inaktivasyonunun doğrusal (basit doğrusal, Kuadritik ve Kubik) ve doğrusal olmayan modeller (Lojistik, Gompertz ve Brody) ile matematiksel olarak ifade edilmesi ve model uygunluğunun tespit edilmesi amaçlanmıștır. Bu amaçla buzdolabı koşullarında gerçekleştirilen 4 günlük depolama süresi boyunca, E.coli düzeyi kontrol grup (yalnızca portakal suyu) ve su kefiri ile fermente edilen portakal suyu örneklerinde günlük olarak belirlenmiştir. Sonuç olarak, kontrol grup örneklerde $4.82 \log \mathrm{kob} / \mathrm{mL}$, fermente portakal suyu örneklerinde ise $5.38 \mathrm{log} \mathrm{kob} / \mathrm{mL}$ düzeyinde bir E.coli inaktivasyonu gerçekleştiği tespit edilmiştir. Kullanılan modellerin hesaplanan determinasyon katsayıları $\left(\mathrm{R}^{2}\right)$ ve hata kareler ortalamaları (HKO) baz alınarak model karşılaştırılması yapıldığında, E.coli inaktivasyonunu $0.998 \mathrm{R}^{2}$ ve $0.025 \mathrm{HKO}$ değerleri ile doğrusal modellerden kübik modelin; $0.995 \mathrm{R}^{2}$ ve $0.053 \mathrm{HKO}$ değerleri ile doğrusal olmayan modellerden ise Brody modelin en uygun model olduğu tespit edilmiştir.

Anahtar Kelimeler: Su kefiri, portakal suyu, Escherichia coli, matematiksel modelleme.

\section{Mathematical modeling of Escherichia coli inactivation in orange juice fermented with water kefir microorganisms}

\begin{abstract}
Water kefir is a homemade fermented beverage based on a sucrose solution with different dried and fresh fruits. The predominant flora in this beverage prepared with water kefir grains is lactic acid bacteria and some yeast species. The aim of study was mathematically express of E.coli inactivation by linear (simple linear, quadratic and cubic) and nonlinear models (Logistics, Gompertz and Brody) in fermented orange juice with water kefir grains and to determine the model suitability. For this purpose, during the storage period for 4 days under refrigerator conditions, E.coli level was determined daily in the control group (orange juice) and orange juice samples fermented with water kefir grains. As a result, it was determined that E.coli inactivation was $4.82 \log \mathrm{cfu} / \mathrm{mL}$ in control group samples and $5.38 \mathrm{log} \mathrm{cfu} / \mathrm{mL}$ in fermented orange juice samples. When the model comparison is made based on the calculated determination coefficients $\left(\mathrm{R}^{2}\right)$ and error squares mean (HKO) of the used models, Cubic model as a linear model was found to be most suitable models with $0.998 \mathrm{R}^{2}$ and $0.025 \mathrm{HKO}$; Brody model was found to be the most suitable model from nonlinear models with $0.995 \mathrm{R}^{2}$ and $0.053 \mathrm{HKO}$ values.
\end{abstract}

Keywords: Water kefir, orange juice, Escherichia coli, mathematical modeling. 


\section{Giriş}

Su kefiri, inokülüm görevi gören polisakkarit taneleri olan su kefir tanelerinin, su, şeker (sakkaroz), kuru incir kullanılarak aktifleştirilmesi sonrasında bileşimine limon ve portakal suyu gibi maddelerin eklenmesiyle elde edilen fermente bir içecektir. İçeceğin tarifi, yapıldığı ülkelere göre değişiklik göstermektedir. Üretim sonrası, oda sıcaklığında $\left(20-25{ }^{\circ} \mathrm{C}\right.$ 'de $) 2$ ila 4 gün anaerobik inkübasyonun ardından, meyveli, asitli, hafif tatlı ve hafif alkollü tadı ve aroması olan köpüklü, sarımsı fermente bir içecek elde edilir (Pidoux, 1989; Gulitz ve ark., 2011; Hsieh ve ark., 2012; Gulitz ve ark., 2013; Stadie ve ark., 2013). Günümüzde, su kefir içeceği ağırlıklı olarak hane düzeyinde gerçekleştirilmektedir, bu nedenle su kefir içimini hazırlamak için kullanılan hammaddeler kişiden kişiye değişmektedir (Hsieh ve ark., 2012). Ticari açıdan su kefir fermantasyon işleminin kontrol edilmesi fermantasyonun kararsızlı̆̆ı nedeniyle zordur ve fermantasyonda değişken son ürünler üretebilir. Ek olarak, su kefir tanesi büyümesi fermantasyonda sıklıkla azalır, bu durum üretim sürecinin başarılı bir şekilde yürütülmesini önler. Fermantasyon sırasında bu problemleri önleyebilmek ve / veya düzeltebilmek ve istikrarlı bir ticari üretim prosesinin gelişmesine izin vermek için, su kefir fermantasyon prosesinin tam olarak anlaşılması gerekir (Kalkan ve Otă̆, 2019).

Su kefir dünya çapında mevcuttur, ancak su kefir tanelerinin asıl kökeninin neresi olduğu hala bilinmemektedir. Polisakkarit tanelerinin Opuntia kaktüs incir bitkisinin yapraklarından kaynaklandığı tahmin edilmektedir. Batı Avrupa'da "su kefir taneleri” isminin kullanılmasının yanı sıra, bu fermente içecek için coğrafi bölgelere bağlı olarak başka isimler de kullanılmaktadır. “Zencefilli bira bitkileri”, “Tibicos”, “Tibi taneleri”, "Kaliforniya arıları”, “Afrika arıları”, “ale fıstığı", “Gilead balsamı”, "Bèbées”, “Japon bira tohumları" ve "şekerli kefir taneleri” bu değişik isimlendirmelere birer örnektir (Gulitz ve ark., 2011).

Günümüzde, su kefirine ilişkin araştırmalar halen çok sınırlıdır ve mevcut bilimsel bilgilerin çoğu, tür çeşitliliği ile ilgilidir. Araştırmalarda genel olarak su kefir taneleri olan polisakkaritinin kimyasal ve yapısal bileşimi incelenmiştir (Laureys ve De Vuyst, 2014). Su kefir tane matriksinin ana bileşeni dekstrandır. Bu ekzopolisakarit (EPS), laktik asit bakterileri tarafından sentezlenir. Farklı araştırmacılar, su kefir tanelerindeki baskın EPS üreticileri olarak farklı bakteri türlerini bildirmişlerdir ve bunlar arasında Lactobacillus casei (iki alt tür) (Gulitz ve ark., 2011), Leuconostoc mesenteroides, Lactobacillus nagelii, Lactobacillus hordei ve Lactobacillus hilgardii bulunmaktadır (Gulitz ve ark., 2011; Hsieh ve ark., 2012). Laktik asit bakterilerinin yanı sıra içeceğin maya ve asetik asit bakterileri de içerdiği bilinmektedir (Davidović ve ark., 2015). Yapılan son çalışmalarda, su kefirinde yeni bir Bifidobacterium türü bulunmuştur, ancak su kefir fermantasyonu sırasında önemi belirsizliğini korumaktadır (Laureys ve ark., 2016). Su kefir fermantasyonu sirasında üretilen ana metabolitler etanol, laktik asit, gliserol, asetik asit ve mannitol iken; ana lezzet verici bileşikler 2- 
metil-1-propanol, izoamil alkol, etil asetat, izoamil asetat, etil heksanoat ve etil oktanoattır (Hsieh ve ark., 2012).

Escherichia coli, insan kolon florasında yer alan Gram negatif, Enterobacteriaceae ailesi içerisinde Escherichia cinsine bağlı fakültatif anaerob çoğunlukla hareketli, sporsuz, çubuk şeklinde bir bakteridir. E. coli genellikle bağırsak lümeni ile zararsız bir şekilde sınırlı kalır, fakat konakçının bağışıklık sistemi zayıfladığı/baskılandığı durumlarda veya gastrointestinal bariyerler ihlal edildiğinde, E. coli'nin normal "patojenik olmayan" türleri bile enfeksiyona neden olabilir. Patojenik E. coli'ye bağlı enfeksiyonlar mukozal yüzeylerle sınırlı olabilir veya vücutta yayılabilir. İdrar yolu enfeksiyonu, sepsis / menenjit ve enterik / diyare hastalığı patojenik E. coli suşları ile enfeksiyondan kaynaklanır (Nataro ve Kaper, 1998; Temelli, 2002).

Mikrobiyel büyümeyi öngören matematiksel bir model, gıda kirliliğini ve ürün raf ömrünü ve ayrıca tedarik zincirlerindeki risk değerlendirmesini etkin bir şekilde değerlendirmede önemli bir rol oynar (Gaspovic ve ark., 2008). Son yıllarda, mikroorganizmaların büyümesini öngörmek için sayısız matematiksel model geliştirilmiştir (IFTS, 1993; Baranyi ve Roberts, 1994). Bu çalışmalarda, araştırmacılar genellikle Bacillus cereus, Staphylococcus aureus, E. coli O157: H7, Salmonella spp. ve Listeria monocytogenes gibi önemli patojenik mikroorganizmalara odaklanmıştır. Prediktif modellerde kullanılan model değişkenleri, $\mathrm{pH}$ ve su aktivitesi gibi dış faktörler ve sıcaklık ve antimikrobiyel ajanlar gibi iç faktörlerdir (Kalkan, 2019). Bu araştırma alanında, mikrobiyolojik büyüme eğrisinin sigmoid şekline dayalı, lojistik model ile modifiye Gompertz denklemi, Gibson ve ark. (1998) ile Baranyi ve Roberts tarafından, en yaygın kullanılan modellerden biri olan lojistik denklemine dayanarak geliştirilmiştir (Pérez-Rodríguez ve Valero, 2013). Bu modellerin bir çeşidi olan inaktivasyon modelleri ise gıda endüstrisinde; et ürünlerinin üretiminde kesme, parçalama, soğutma, paketleme ve dağıtım gibi değişik aşamalarında, et ve süt ürünlerinin raf ömürlerinin tespitinde, fermantasyonda kullanılan özel starter kültürlerin kontrolünde, etken mikroorganizmaların gelişmesi için gerekli ortam şartlarının sağlanmasında, ürün üretiminde kullanılan farklı proseslerin optimizasyonunda ve üretimde kullanılan gıda katkı maddelerinin hedef mikroorganizma üzerindeki etkilerinin belirlenmesinde kullanılmaktadır (Kalkan, 2016).

Su kefiri fermantasyonunu gerçekleştiren mikroorganizmalar arasında probiyotik türlerinde yer aldığı tespit edilmiştir. (Kalkan ve Otağ, 2019). Probiyotikler, yeterli miktarlarda alındıklarında insan sağlığı üzerinde yararlı etkileri olan canlı mikroorganizmalar olarak tanımlanmaktadır. Probiyotik bakterilerin sağlık üzerinde bağışıklık sistemini güçlendirme, gastrointestinal enfeksiyonları, diareyi ve gıda kaynaklı bazı alerjileri önleme gibi faydaları olduğu bilinmektedir (Erginkaya ve ark., 2019). Probiyotik mikroorganizmalar olarak florada ağırlıklı olarak yer alan laktik asit bakterileri diğer mikroorganizmalara karşı gösterdiği antagonistik aktivite, ürettikleri laktik ve asetik asit gibi organik asitler, $\mathrm{H}_{2} \mathrm{O}_{2}$, bakteriyosin veya bakteriyosin benzeri metabolitler, diasetil, alkol ve $\mathrm{CO}_{2}$ gibi 
metabolitlerden kaynaklanmaktadır (Çon ve Gökalp, 2000). Bu çalışmada, gıda kaynaklı patojen mikroorganizmalardan olan E. coli'nin probiyotik su kefiri mikroorganizmaları kullanılarak üretilen portakal suyunda, buzdolabı koşullarında gerçekleştirilen 4 günlük depolama boyunca inaktivasyonun, farklı matatematiksel modeller kullanılarak ifadesi amaçlanmıştır.

\section{Materyal ve Metot}

\subsection{Materyal}

Bu çalışmada materyal olarak kullanılan; su kefiri üretimi için gerekli olan su kefiri kültürü, Canberk Gıda İhtiyaç Mad. Nak. San. ve Tic. Ltd. Şti.'den (Yenimahalle/ Ankara), portakal suyu üretimde kullanılan portakallar ise Giresun semt pazarlarından, Ocak-Şubat 2019 ayları arasında temin edilmiştir. Su kefiri mikroorganizmaları ile fermente edilen portakal sularının analizleri Giresun Üniversitesi Gıda Mühendisliği Bölümü laboratuvarlarında gerçekleştirilmiştir.

\subsection{Su kefiri mikroorganizmaları ile fermente edilen portakal suyu üretimi}

Su kefiri mikroorganizmaların aktifleştirilmesi işlemi için 200 mL'lik temiz, cam kavanoz içerisine klorsuz içme suyu konulmuş ve su kefiri taneleri bu su içerisinde oda sıcaklığında 15 dakika bekletilmiştir. Ardından, su kefiri taneleri süzülerek, içerisinde 20 gram sakkaroz bulunan 1 L'lik içme suyu içerisine ilave edilmiş ve 10 adet çekirdeksiz kuru üzüm ile birlikte 2 gün boyunca oda sıcaklığında, ağzı tülbentle kapatılmış cam kavanoz içerisinde fermantasyona tabi tutulmuştur. Ön fermantasyon sonrası aktifleşen su kefiri mikroorganizmaları, 1 litre taze sıkılmış portakal suyu içerisine ilave edilerek, ağzı kapalı bir cam kavanoz içerisinde tekrar 2 gün boyunca, oda sıcaklığında devam edecek ana fermantasyon işlemi gerçekleştirilmiştir. Denemede kontrol grubu olarak fermente edilmemiş, taze sıkılmış portakal suyu kullanılmıştır. Aktifleştirilmiş su kefiri taneleri ile portakal suyu üretimi Şekil 1'de gösterilmiştir (Fels ve ark., 2018). Portakal sularının üretiminde 1sıl işlem yöntemi uygulanmadığı için, ürünlerin duyusal ve diğer fizikokimyasal özelliklerinin en iyi korunduğu ilk 4 günlük süre, çalışmada depolama süresi olarak seçilmiştir. 


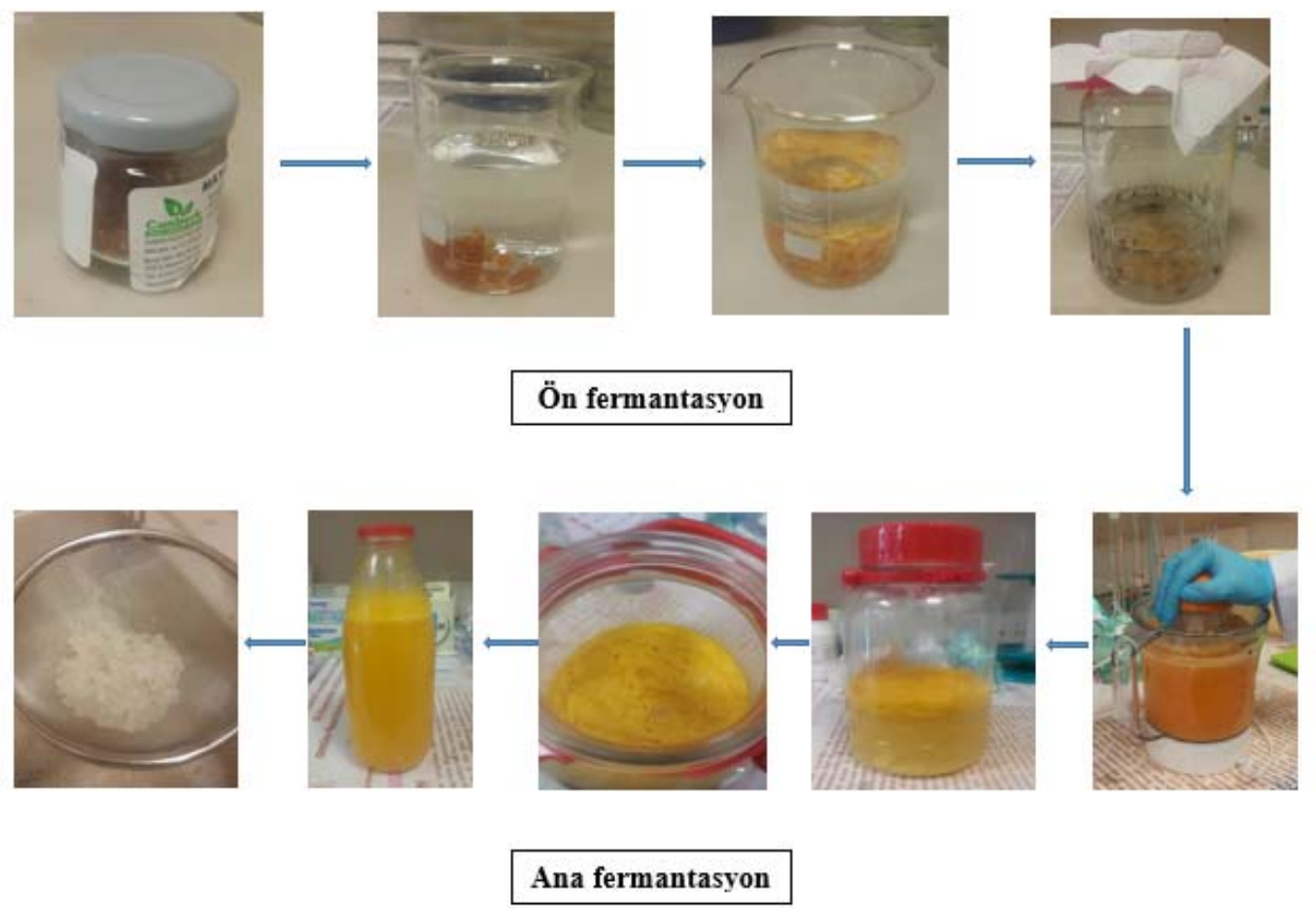

Şekil 1. Su kefiri taneleri ile portakal suyu üretimi

\subsection{Escherichia coli inokülasyonu}

Escherichia coli Tip 1, test mikroorganizması olarak kullanılmıştır. Seçici besiyerinde büyütülen her bir koloni, $5 \mathrm{~mL}$ Nutrient Broth (Merck) ortamı içine aşılanmış ve $37^{\circ} \mathrm{C}^{\prime} \mathrm{de} 18-24$ saat inkübasyona bırakılmıştır. İnkübasyon sonrası, $0.5 \mathrm{Mc}$ Farland standardına tekabül eden 1-2 x $10^{6}$ kob/mL hücre içeren bakteri kültürlerinden stok kültürler hazırlanmış ve portakal sularının inokülasyonunda bu konsantrasyon kullanılmıştır.

\subsection{Kimyasal ve mikrobiyolojik analizler}

Fermente edilmiş ve edilmemiş portakal suları, üretimlerini takiben depolamanın $\quad 0 ., 1 ., 2 ., 3$. ve 4. günlerinde kimyasal ve mikrobiyolojik analizleri yapılmıştır. Örneklerinin pH'sı, pH metre kullanılarak (Ohaus, Starter2100 pH Bench pH meter ST2100-F) belirlenmiştir. Örneklerin toplam asitlik tayini, sitrik asit cinsinden belirlenmiş olup, $10 \mathrm{~mL}$ örnek üzerine $20 \mathrm{~mL}$ saf su ilavesi sonrası pH 8.1 olana kadar $0.1 \mathrm{~N} \mathrm{NaOH}$ ile titrasyon yapılarak tespit edilmiştir (AOAC, 2005).

Örneklerin depolama süresi boyunca toplam laktik asit bakterisi (LAB), toplam maya-küf ve $E$. coli sayımları gerçekleştirilmiştir. Mikrobiyel sayımlar için, $10 \mathrm{~mL}$ fermente edilmiş ve edilmemiş portakal suyu örnekleri, $90 \mathrm{~mL}$ steril dilüsyon sıvısı ile (MRD; Merck-Germany) 2 dakika boyunca homojenize edilmiştir. Homojenize edilen örneklerden $1 \mathrm{~mL}$ alınmış ve dilüsyon sıvısı kullanılarak 
seyreltme yapılmıştır. Daha sonra $0.1 \mathrm{~mL}$ seyreltilmiş örnekler toplam LAB sayımı için de Man, Rogosa Sharpe (MRS) Agar'a (Merck-Germany), toplam maya-küf sayımı için Potato Dextrose Agar (PDA; Merck-Germany), E. coli sayımları için ise Violet Red Bile Agar'a (VRB; Merck-Germany) yayma ekim yöntemiyle ekilmiştir. Ekimi yapılan petri kutuları toplam LAB sayımı için $37^{\circ} \mathrm{C}^{\prime}$ de anaerobik koşullarda 48 saat, E.coli sayımı için $37^{\circ} \mathrm{C}$ 'de 24 saat, toplam maya-küf sayımı için ise 30 ${ }^{\circ} C^{\prime}$ de 72 saat boyunca inkübasyona bırakılmışlardır (FDA, 1998).

\subsection{Matematiksel modeller}

Sayım sonuçlarına göre, su kefiri mikroorganizmaları ile fermente edilmiş portakal suyuna inoküle edilen E.coli'ye karşı gelişen antimikrobiyel etkiyi açıklayan en iyi matematiksel modelin tespitinde Tablo 1'de belirtilen doğrusal ve doğrusal olmayan modellerden yararlanılmıştır.

Tablo 1. Araştırmada kullanılan doğrusal ve doğrusal olmayan matematiksel modeller

\begin{tabular}{ll}
\hline Model & Eşitlik \\
\hline Doğrusal modeller & \\
\hline Basit doğrusal & $\mathrm{Y}_{\mathrm{t}}=\mathrm{A}+\mathrm{bt}$ \\
Kuadritik & $\mathrm{Y}_{\mathrm{t}}=\mathrm{A}+\mathrm{b}_{1} \mathrm{t}+\mathrm{b}_{2} \mathrm{t}^{2}$ \\
Kubik & $\mathrm{Y}_{\mathrm{t}}=\mathrm{A}+\mathrm{b}_{1} \mathrm{t}+\mathrm{b}_{2} \mathrm{t}^{2}+\mathrm{b}_{3} \mathrm{t}^{3}$ \\
\hline Doğrusal olmayan modeller* & \\
\hline Lojistik & $\mathrm{Y}_{\mathrm{t}}=\mathrm{A}(1+\mathrm{B} \exp (-\mathrm{kt}))^{-1}$ \\
Gompertz & $\mathrm{Y}_{\mathrm{t}}=\mathrm{A} \exp (-\mathrm{B} \exp (-\mathrm{kt}))$ \\
Brody & $\mathrm{Y}_{\mathrm{t}}=\mathrm{A}(1-\mathrm{B} \exp (-\mathrm{kt}))$ \\
\hline *exp: matematiksel üstel fonksiyon &
\end{tabular}

Modellerde;

$\mathrm{Y}_{\mathrm{t}} \mathrm{t}$ zamanda tespit edilen mikroorganizma konsantrasyonu

t: Zaman

Doğrusal modellerde;

A, Araştırılan özellik bakımından doğrunun y eksenini kestiği başlangıç değeridir. b1, b2 ve b3 ve ise doğrusal modellere ait regresyon katsayılarıdır.

Doğrusal olmayan modellerde ise;

A: Maksimum mikroorganizma konsantrasyonu,

B: $t_{1}$ zamandaki mikroorganizma konsantrasyonunun, $t_{s}$ zamandaki mikroorganizma konsantrasyonuna oran1,

k: Logaritmik artış hızı, bu parametre mikroorganizma konsantrasyonunun hangi hızla maksimum mikroorganizma konsantrasyonuna yaklaştığını göstermektedir. 
A, B ve k parametreleri, SPSS 20 istatistik paket programı kullanılarak genelleştirilmiştir. Parametreler, en küçük kareler yöntemi ve Levenberg-Marquardt iterasyon işlemi ile tahminlenmiştir. İterasyon işleminde, yakınsama kriteri olarak 1.0E-8 kullanılmıştır. Çalışmada kullanılan modellerin karşılaştırılmasında, toplam varyasyonda modelin açıkladığı kısmı gösteren $\mathrm{R}^{2}$ (belirleme katsayısı), HKO (hata kareler ortalaması) ve modele ait tahminlenen inaktivasyon eğrisi kullanılmıştır (Kalkan 2016).

\section{Bulgular ve Tartışma}

Portakal suyu (Kontrol-P) ile su kefiri ile fermente edilen portakal suyunun (SK-P), buzdolab1 koşullarında depolanması süresince $\mathrm{pH}$ ve titrasyon asitliği (\%) sonuçları Tablo 2'de gösterilmiştir.

Tablo 2. Depolama süresi boyunca ürünlerin kimyasal özelliklerinde değişimler

\begin{tabular}{ccccc}
\hline & \multicolumn{2}{c}{$\mathbf{p H}^{*}$} & \multicolumn{2}{c}{ Titrasyon asitliği (\%)* } \\
\hline $\begin{array}{c}\text { Depolama } \\
\text { zamanı (gün) }\end{array}$ & Kontrol-P & SK-P & Kontrol-P & SK-P \\
\hline $\mathbf{0}$ & $4.21 \pm 0.00^{\mathrm{aA}}$ & $4.35 \pm 0.00^{\mathrm{aB}}$ & $0.083 \pm 0.00^{\mathrm{aB}}$ & $0.094 \pm 0.00^{\mathrm{CC}}$ \\
$\mathbf{1}$ & $4.23 \pm 0.02^{\mathrm{aA}}$ & $4.51 \pm 0.02^{\mathrm{cB}}$ & $0.087 \pm 0.00^{\mathrm{aBC}}$ & $0.085 \pm 0.00^{\mathrm{bB}}$ \\
$\mathbf{2}$ & $4.21 \pm 0.02^{\mathrm{aA}}$ & $4.54 \pm 0.00^{\mathrm{cB}}$ & $0.087 \pm 0.00^{\mathrm{bBC}}$ & $0.082 \pm 0.00^{\mathrm{bB}}$ \\
$\mathbf{3}$ & $4.23 \pm 0.01^{\mathrm{aA}}$ & $4.48 \pm 0.00^{\mathrm{bB}}$ & $0.085 \pm 0.00^{\mathrm{bBC}}$ & $0.081 \pm 0.00^{\mathrm{bB}}$ \\
$\mathbf{4}$ & $4.29 \pm 0.01^{\mathrm{bA}}$ & $4.52 \pm 0.00^{\mathrm{cB}}$ & $0.079 \pm 0.00^{\mathrm{aAB}}$ & $0.074 \pm 0.00^{\mathrm{aA}}$ \\
\hline
\end{tabular}

*a-c: aynı sütun içerisinde farklı harflerle gösterilen ortalamalar arasındaki fark istatistiksel olarak önemlidir ( $\mathrm{p} \leq 0.05)$. A-C: aynı satır içerisinde farklı harflerle gösterilen ortalamalar arasındaki fark istatistiksel olarak önemlidir $(\mathrm{p} \leq 0.05)$

Tablo 2'de de görüldügü gibi Kontrol-P grubu örnekleri ile SK-P grubu örneklerinin pH değeri arasındaki fark istatiksel olarak önemlidir $(\mathrm{p} \leq 0.05)$. Her iki grup örnekler için depolama günü ile $\mathrm{pH}$ değeri değişimi arasındaki ilişki ise istatiksel olarak önemli değildir ( $\mathrm{p} \leq 0.05)$. Portakal suyu örnekleri titrasyon asitliği (\%) değerleri açısından karşılaştırıldığında ise, her iki grup arasındaki fark istatiksel olarak önemlidir $(\mathrm{p} \leq 0.05)$. pH değerlerinden farklı olarak, örneklerin depolama gününe bağlı olarak titrasyon asitliği (\%) değerlerinin değişimleri de istatiksel olarak önemli bulunmuştur ( $\mathrm{p} \leq 0.05)$.

Kontrol-P ile SK-P örneklerinin, buzdolabı koşullarında depolanması süresince toplam laktik asit bakteri sayım sonuçları ile toplam maya-küf sayım sonuçları Tablo 3'de gösterilmiştir. 
Tablo 3. Depolama boyunca toplam LAB ve maya-küf sayım sonuçları $(\log \mathrm{kob} / \mathrm{mL})$

\begin{tabular}{ccccc}
\hline & \multicolumn{2}{c}{ LAB* } & \multicolumn{2}{c}{ Maya-Küf* } \\
\hline $\begin{array}{c}\text { Depolama } \\
\text { zamanı (gün) }\end{array}$ & Kontrol-P & SK-P & Kontrol & SK-P \\
\hline $\mathbf{0}$ & $3.19 \pm 0.09^{\mathrm{aA}}$ & $7.67 \pm 0.43^{\mathrm{aB}}$ & $3.51 \pm 0.18^{\mathrm{bA}}$ & $7.75 \pm 0.35^{\mathrm{aB}}$ \\
$\mathbf{1}$ & $3.20 \pm 0.04^{\mathrm{Aa}}$ & $7.44 \pm 0.07^{\mathrm{aB}}$ & $3.03 \pm 0.19^{\mathrm{aA}}$ & $7.69 \pm 0.02^{\mathrm{aB}}$ \\
$\mathbf{2}$ & $3.26 \pm 0.01^{\mathrm{abA}}$ & $7.54 \pm 0.04^{\mathrm{aB}}$ & $3.19 \pm 0.07^{\mathrm{abA}}$ & $7.74 \pm 0.02^{\mathrm{aB}}$ \\
$\mathbf{3}$ & $3.43 \pm 0.07^{\mathrm{abA}}$ & $7.72 \pm 0.02^{\mathrm{aB}}$ & $3.87 \pm 0.04^{\mathrm{AA}}$ & $7.86 \pm 0.03^{\mathrm{aB}}$ \\
$\mathbf{4}$ & $3.50 \pm 0.15^{\mathrm{bA}}$ & $9.19 \pm 0.71^{\mathrm{aC}}$ & $4.10 \pm 0.04^{\mathrm{cA}}$ & $7.93 \pm 0.01^{\mathrm{aC}}$ \\
\hline
\end{tabular}

*a-c: aynı sütun içerisinde farklı harflerle gösterilen ortalamalar arasındaki fark istatistiksel olarak önemlidir ( $\mathrm{p} \leq 0.05)$. A-C: aynı satır içerisinde farklı harflerle gösterilen ortalamalar arasındaki fark istatistiksel olarak önemlidir $(\mathrm{p} \leq 0.05)$

Tablo 3'de de görüldüğü gibi su kefiri ile üretilen portakal sularında hem toplam LAB sayıs1 hem de toplam maya-küf sayısı artış göstermiştir ve bu artış istatiksel olarak önemlidir $(\mathrm{p} \leq 0.05)$. $\mathrm{Bu}$ artış özellikle toplam LAB bakteri sayısında depolamanın son gününde dikkat çekicidir. LAB sonuçlarının yüksek olması özellikle organik asit, diasetil, asetoin, hidrojen peroksit, reuterin, antifungal peptitler ve bakteriyosinler gibi çok çeşitli antimikrobiyel bileşikleri üretebilme kapasitesine sahip olmaları nedeniyle önemlidir (Dinçer ve ark., 2009). Çalışmamız sonuçlarında, önceki çalışmalara benzer olarak, maya ve laktik asit bakteri sayısının fermente portakal suyu örneklerinde oldukça yoğun olduğu bulunmuştur. Gulitz ve ark. (2011), esas olarak, su kefiri mikrobiyel florasının, gram granül başına $10^{8} \log$ kob laktobasil, $10^{6}-10^{8} \log$ kob asetik asit bakterileri ve $10^{6}-10^{7} \log$ kob mayadan oluştuğunu bildirmiştir. Kefir tanelerinin LAB'leri, Lactobacillus, Lactococcus ve Leuconostoc spp. türlerine aittir (Davidović ve ark., 2015). Araştırmacılar, bu laktik asit bakterilerini, Lactobacillus nagelii, Lactobacillus hordei, Lactobacillus hilgardii, Lactobacillus casei, Leuconostoc mesenteroides ve Leuconostoc citreum olarak tanımlanmışladır. Ayrıca, Acetobacter türleri (Acetobacter fabarum ve Acetobacter orientalis) de tanımlanan türler arasındadır (Gulitz ve ark., 2011). Leroi ve Pidoux (1993), Lb. hilgardii ve Saccharomyces florentinus' in de su kefir tanelerinde bulunduğunu tespit etmişlerdir.

Depolama süreci boyunca su kefiri ile fermente edilen portakal suyuna inoküle edilmiş E.coli inaktivasyonu Şekil 2'de'gösterilmiştir. Şekil 2'de görüldüğü üzere hem portakal suyu örneklerinde hem de fermente örneklerde E. coli inaktivasyonu depolama boyunca gerçekleşmiştir. Fermente portakal sularında gerçekleşen inaktivasyon (5.38 log kob/mL), portakal suyu örneklerine (4.82 log kob/mL) kıyasla daha yüksek oranda gerçekleşmiştir. Gerçekleşen inaktivasyonda su kefiri mikroorganizmaları tarafından üretilen organik asitler (laktik ve asetik asit) ile diğer sekonder metabolitlerin ve ürün $\mathrm{pH}$ değişimlerinin etkisi olduğu düşünülmektedir. 


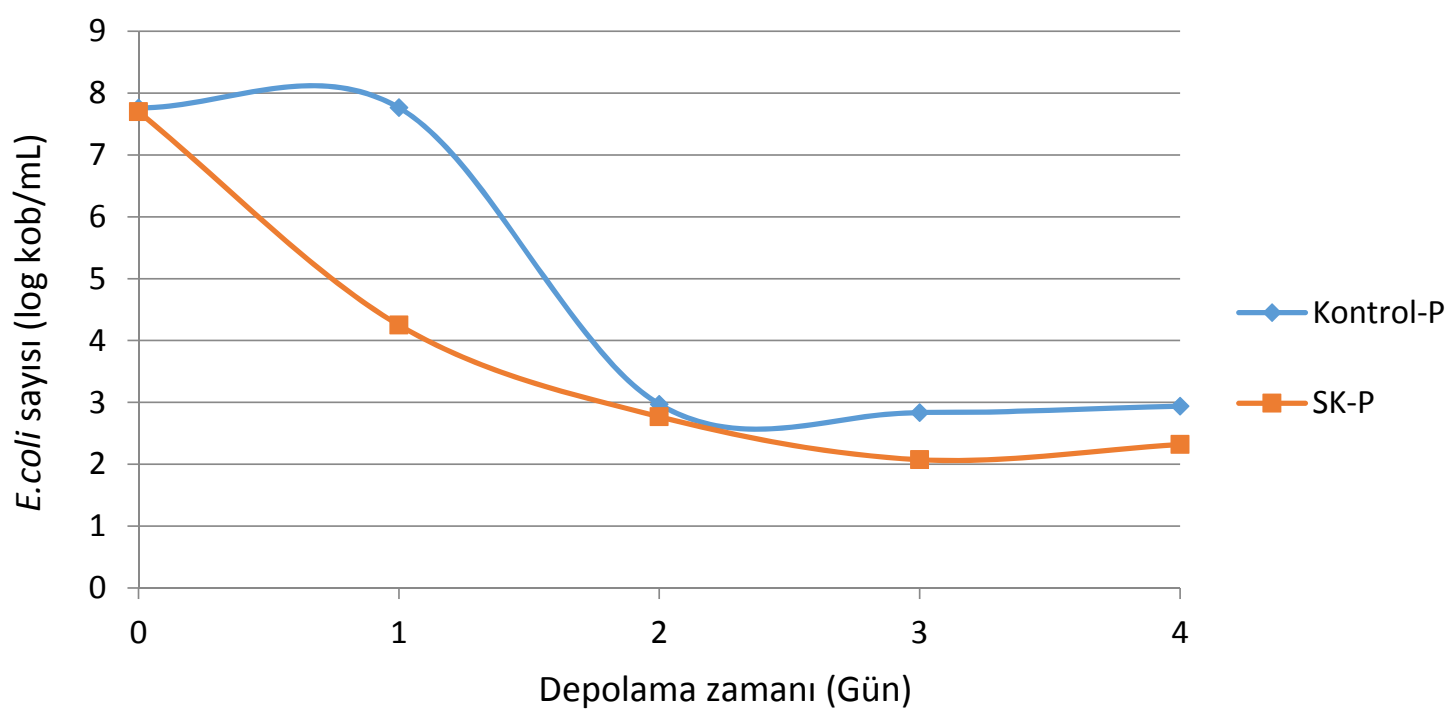

Şekil 2. Zaman bağlı olarak E.coli inaktivasyon eğrisi

Su kefirine inoküle edilen E. coli'nin 4 günlük buzdolabı koşullarında gerçekleşen inaktivasyonun doğrusal (Basit doğrusal, kuadritik ve kübik) ve doğrusal olmayan (Lojistik, Gompertz ve Brody) modeller ile analizi sonucu tahminlenen model parametreleri, hata kareler ortalamaları (HKO) ve belirleme katsayıları $\left(\mathrm{R}^{2}\right)$ Tablo 4'de gösterilmiştir.

Tablo 4. E. coli inaktivasyonun matemetiksel modellerle analizi sonucu tahminlenen parametreler

\begin{tabular}{|c|c|c|c|c|c|c|c|c|c|c|c|}
\hline \multicolumn{7}{|c|}{ Doğrusal modeller } & \multicolumn{5}{|c|}{ Doğrusal olmayan modeller } \\
\hline Modeller & Parametreler & $\mathbf{X}$ & Sx & HKO & $\mathbf{R}^{2}$ & Modeller & Parametreler & $\mathbf{X}$ & $\mathbf{S x}$ & HKO & $\mathbf{R}^{2}$ \\
\hline \multirow{2}{*}{$\begin{array}{c}\text { Basit } \\
\text { doğrusal }\end{array}$} & $\mathbf{A}$ & 6.410 & 0.607 & & & \multirow{3}{*}{ Logistic } & $\mathbf{A}$ & 7.256 & 0.056 & \multirow{3}{*}{0.193} & \multirow{3}{*}{0.982} \\
\hline & b & -1.294 & 0.248 & 1.639 & 0.773 & & $\mathbf{B}$ & -0.736 & 0.008 & & \\
\hline \multirow{3}{*}{ Kuadratik } & $\mathbf{A}$ & 7.578 & 0.135 & & & & $\mathbf{k}$ & 0.441 & 0.046 & & \\
\hline & b1 & -3.629 & 0.039 & 0.064 & 0.994 & \multirow{3}{*}{ Gompertz } & $\mathbf{A}$ & 7.452 & 0.063 & \multirow{3}{*}{0.100} & \multirow{3}{*}{0.990} \\
\hline & b2 & 0.584 & 0.002 & & & & B & -1.333 & 0.021 & & \\
\hline \multirow{4}{*}{ Kubik } & $\mathbf{A}$ & 7.681 & 0.215 & \multirow{4}{*}{0.025} & \multirow{4}{*}{0.998} & & $\mathbf{k}$ & 0.674 & 0.045 & & \\
\hline & b1 & -4.367 & 0.112 & & & \multirow{3}{*}{ Brody } & $\mathbf{A}$ & 7.628 & 0.019 & \multirow{3}{*}{0.053} & \multirow{3}{*}{0.995} \\
\hline & b2 & 1.099 & 0.016 & & & & B & -2.786 & 0.058 & & \\
\hline & b3 & -0.086 & 0.000 & & & & $\mathbf{k}$ & 0.993 & 0.046 & & \\
\hline
\end{tabular}

E. coli için mikroorganizma konsantrasyonuna ait doğrusal ve doğrusal olmayan modeller kullanılarak çizilen zamana bağlı inaktivasyon eğrileri ise Şekil 3 ve Şekil 4'de gösterilmiştir. 


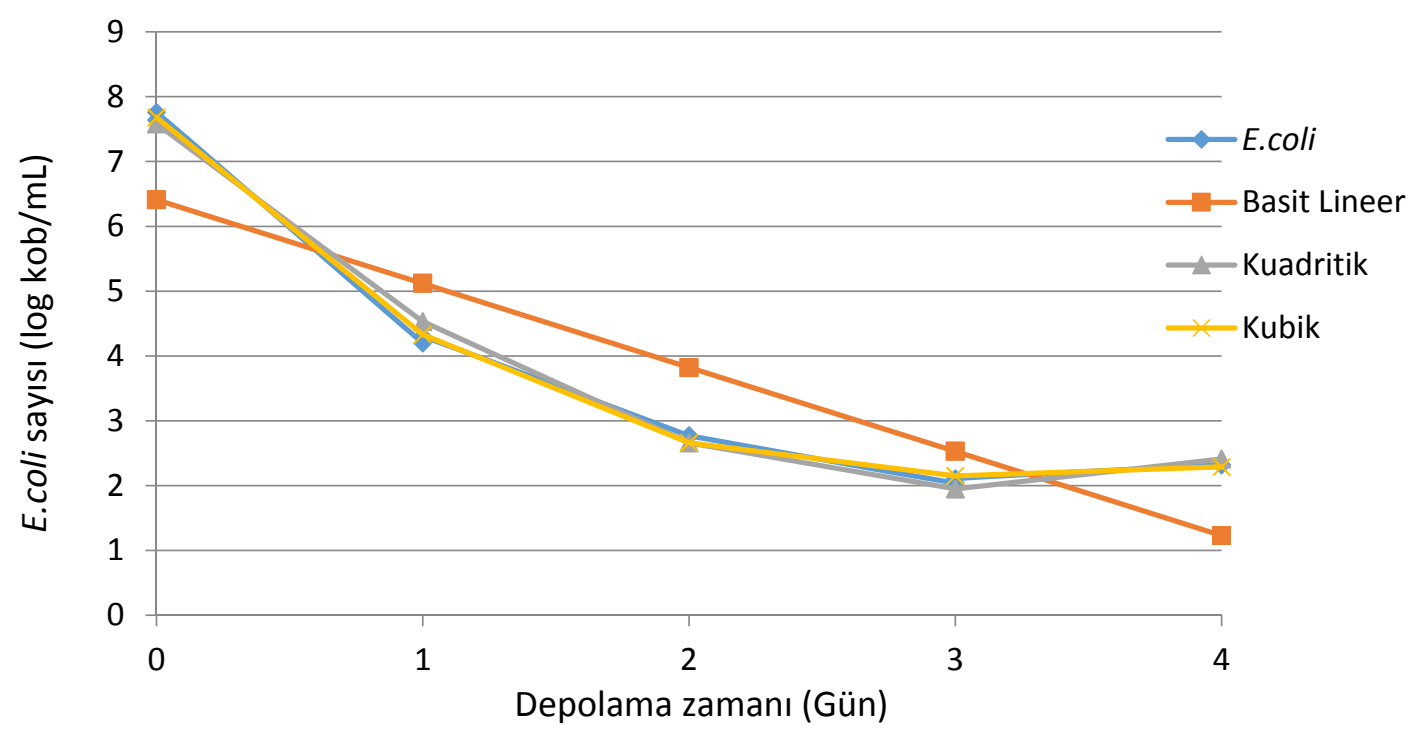

Şekil 3. E. coli konsantrasyonunun doğrusal modellere göre tahminlenen konsantrasyon değişimi (log $\mathrm{kob} / \mathrm{mL}$ )

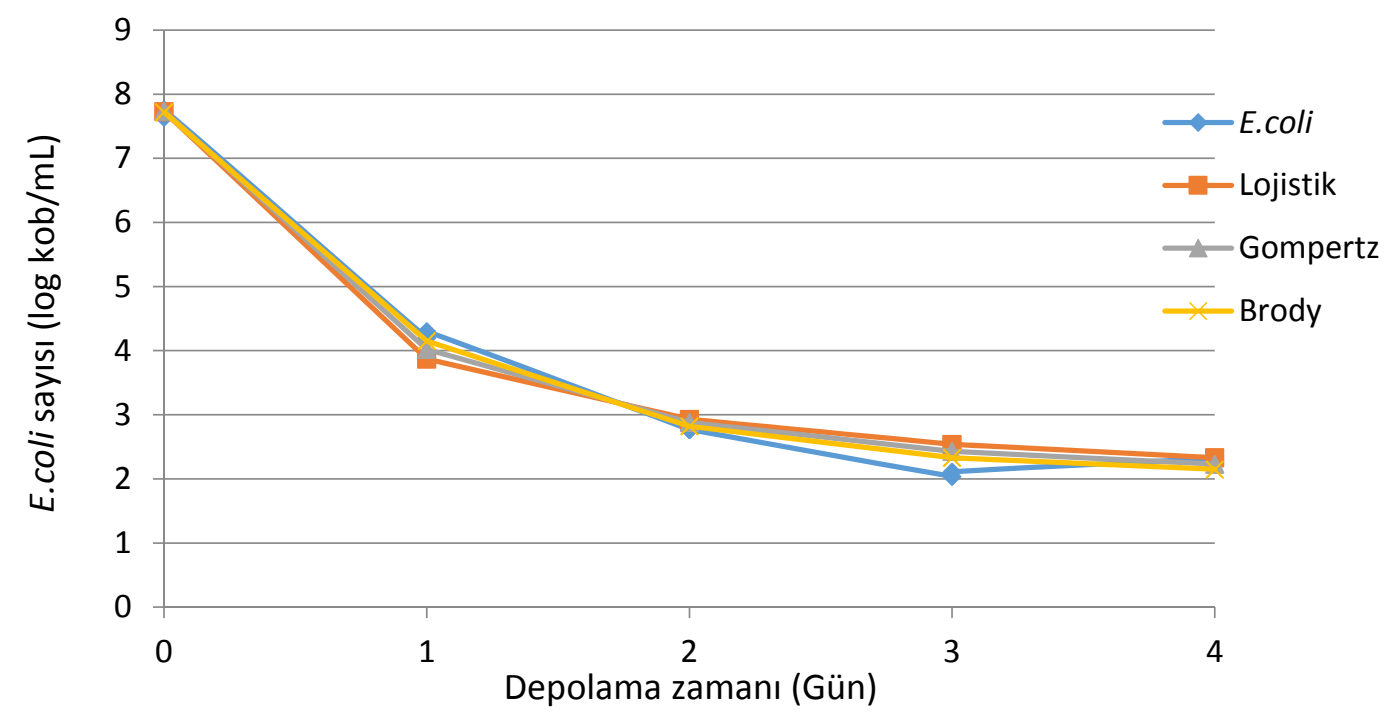

Şekil 4. E. coli konsantrasyonunun doğrusal olmayan modellere göre tahminlenen konsantrasyon değişimi $(\log \mathrm{kob} / \mathrm{mL})$

Laktik asit bakterileri, sağlık ve beslenmedeki faydaları ve fermentatif özelliklerinden dolayı gıda endüstrisinde özel öneme sahip mikroorganizmalar olarak bilinirler. Laktik asit bakterileri, genel olarak glikozu laktik asite çevirmeleri ile karakterize edilmektedirler. Bunun yanı sıra organik asitler, hidrojen peroksit, diasetil, bakteriyosin ve benzeri bileşikler üretebilme kabiliyetine sahiptirler. Laktik asit bakterilerinin oluşturduğu antimikrobiyel etmen ve özellikleri, pH'nın ve peptid olmayan inhibitörlerin oluşumu, antibakteriyel etkiye sahip $\mathrm{H}_{2} \mathrm{O}_{2}$ ile asetik, ketoglutarik, melonik asit gibi organik asitleri içeren diğer bileşiklerin oluşumu ve bakteriyosinlerden kaynaklanmaktadır. Gıda kaynaklı patojen olan veya olmayan kontaminantların büyük bir çoğunluğu fermantasyon sonucu oluşan organik asitlere ve dolayısıyla pH düşüşüne karşı hassastır (Evren ve ark., 2006). Son yıllarda 
laktik asit bakterilerinin ağırlıklı olduğu fermente ürünlerde patojen mikroorganizmaların inaktivasyonuna yönelik çalışmalar ağırlıklıdır. Laktik asit bakterilerinin önemli bir kısmından oluşan probiyotik bakterilerin sentezlediği bakteriyosinlerin, Staphylococcus aureus ve Clostridium perfringens gibi Gram pozitif özellikteki bakterilere karşı, Salmonella Typhimurium ve Escherichia coli gibi Gram negatif özellikteki bakterilerden daha etkili antibakteriyel etki gösterdiği bilinmektedir. Patojen bakterilere karşı, tek başına laktik asit veya $\mathrm{H}_{2} \mathrm{O}_{2}$ uygulamasından ziyade organik asitlerle birlikte gıda ortamında hidrojen peroksit varlığının daha etkili olduğu tespit edilmiştir (Sağdıç ve ark., 2004). Taş ve ark. (2017) probiyotik özellikteki Lactobacillus acidophilus NCC68, Lactobacillus casei Shirota, Lactobacillus rhamnosus suşlarının Bacillus cereus, Salmonella Enteritidis, Escherichia coli, Escherichia coli 0157:H7 ATCC 35150 ve Staphylococcus aureus ATCC 25923 üzerine inhibisyon etkilerini araştırmışlardır. Çalışmada kullanılan laktik asit bakterilerinin tüm mikroorganizmalara karşı antimikrobiyel etki gösterirken, en dirençli şusun $B$. cereus, en hasssas şusun ise Staphylococcus aureus ATCC 25923 olduğu tespit edilmiştir. Chuayana ve ark. (2003), süt ürünlerinde izole edilen probiyotik laktik asit bakterilerinin antimikrobiyel aktivitesini incelemişler ve $L$. casei'nin, S. aureus, E. coli, P. aeruginosa, S. Typhi ve S. marcescens gibi patojenlere karşı bakteriyostatik etki gösterdiğini bildirmişlerdir. Benzer şekilde Aslım ve ark. (2005) L. acidophilus'un çalışmalarında S. aureus, E. coli ve Y. enterocolitica üzerinde antibakteriyel aktivite gösterdiğini tespit etmişlerdir. Çalışmamız sonuçları literatürle uyumlu olarak, E. coli'nin inaktivasyonunda su kefiri mikroorganizmalarının etkili olduğunu ortaya koymuştur.

Matematiksel prediktif (tahminleyici) modeller, benzeri koşullarda deney yapılmasına gerek duyulmadan tahminde bulunulmasına izin verdiği için oldukça önemlidir. Bu amaçla kullanılan doğrusal ve doğrusal olmayan birçok model bulunmaktadır. Bu modellerden deney koşullarına göre tahmin isabeti açısından en uygun olanını tespit etmenin en basit yolu determinasyon katsayılarını ( $\mathrm{R}^{2}$ ) karşılaştırmaktadır (Kalkan, 2016; Külcü ve ark., 2019). Tablo 4 ve Şekil 1-2'de gösterildiği gibi, doğrusal modeller (Basit doğrusal, Kuadratik ve Kubik) kendi aralarında kıyaslandığında, modellerin determinasyon katsayılarının $\left(\mathrm{R}^{2}\right)$ sırasıyla $0.773,0.994$ ve 0.998 olduğu, hata kareler ortalamalarının (HKO) ise sırasıyla 1.638, 0.064 ve 0.025 olduğu görülmektedir. $\mathrm{R}^{2}$ değerinin 1 'e yakın, HKO ortalamasının ise en düşük olması açısından, doğrusal modeller karşılaştırıldığında model uygunluğu açısından en uygun modelin "Kubik model” olduğu tespit edilmiştir. Doğrusal olmayan modellerin (Logistik, Gompertz, Brody) $\mathrm{R}^{2}$ değerlerinin ise sırasıyla 0.982, 0.990 ve 0.995 olduğu, HKO ortalamalarının sırasıyla $0.193,0.100$ ve 0.053 olduğu görülmektedir. Doğrusal olmayan modeller, model uygunluğu açısından karşılaştırıldığında en uygun modelin ise "Brody model" olduğu belirlenmiştir. Literatürde, patojen inaktivasyonunun matematiksel olarak modellendiği ve tahminlendiği birçok çalışma yer almaktadır. Bu çalışmalardan biri olarak, Virto ve ark. (2006) Listeria monocytogenes ve Escherichia coli' nin sitrik (10-150 $\left.\mathrm{g} \mathrm{L}^{-1}\right)$ ve laktik (1-60 mL 
$\left.\mathrm{L}^{-1}\right)$ asitlerin varlığında, farklı sicaklıklarda $\left(4,20,40{ }^{\circ} \mathrm{C}\right)$ inaktivasyonunu Weibull modelini kullanarak incelenmiştir. Her iki asidin bakterisidal etkisini, maruz kalınan zamana, ortam sıcaklığına ve asit konsantrasyonuna bağlı olarak tahminlemişlerdir ve her iki organik asite maruz bırakılmış $E$. coli'nin sağkalım eğrilerinin yukarı doğru içbükey olarak belirtmişlerdir. Sonuç olarak araştırmacılar, Weibull dağılımına dayanan matematiksel bir modelin, her iki asitin kullanımında, her iki mikroorganizmanın da inaktivasyon kinetiğini doğru bir şekilde tarif ettiğini tespit etmişlerdir. Bu model, L. monocytogenes ve E. coli'nin asit direncinin nicelendirilmesine ve karşılaştırılmasına izin veren bir model olarak belirtilmiştir. Asitlerin inaktivasyon etkileri karşılaştırıldığında laktik asitin, sitrik asitten daha etkili olduğu ve E. coli'nin her iki aside karşı da L. monocytogenes'den daha hassas olduğu tespit edilmiştir. Benzer bir çalışmada Tsujihata ve ark. (1998), asetik asit, sıcaklık ve sodyum klorürün Escherichia coli O157: H7 inaktivasyonu üzerindeki kombine etkileri, işlenmişs sirkede incelenmişlerdir. Kombine etkiyi ifade etmek için ikinci dereceden polinom modelleri uygulanmıştır. Araştırma sonucunda, kullanılan polinom modellerinin yüksek determinasyon katsayısına $\left(\mathrm{R}^{2}\right.$ sırasıyla 0.988 ve 0.978 ) sahip olduğu tespit edilmiştir. Raffelli ve ark. (2008) tarafından yapılan farklı bir çalışmada ise, Escherichia coli ATCC 35218'in farklı konsantrasyonlarda (ağırlıkça\% 03.00) hidrojen peroksit çözeltilerinde ve $25{ }^{\circ} \mathrm{C}^{\prime} \mathrm{de}$ farklı $\mathrm{pH}$ değerlerinde (3.0-7.2) inaktivasyon kinetiği incelenmiştir. $\mathrm{H}_{2} \mathrm{O} 2$ çözeltilerinin E. coli ATCC 35218'e karş1 etkinliği, hem yüksek $\mathrm{H}_{2} \mathrm{O}_{2}$ konsantrasyonlarında hem de daha fazla asidik pH değerlerinde etkinlik göstermiştir. $\mathrm{H}_{2} \mathrm{O}_{2}$ seviyesi indirgenirken, çözeltinin pH'ının E. coli inhibisyonu oranı üzerindeki etkisi daha ön plana çıkmıştır. İnaktivasyon semilogaritmik eğrilerinin çoğunun doğrusal olmadiğı tespit edilmiştir. İnaktivasyon kinetiğgi, Weibull tipi model dağılımı kullanılarak modellenmiştir. $\mathrm{H}_{2} \mathrm{O}_{2}$ konsantrasyonunun ve pH'ın mikrobiyal popülasyonu azaltmak için gereken maruz kalma süresi üzerindeki etkisini ifade etmek için kuadratik polinom modelleri uygulanmıştır.

\section{Sonuçlar ve Öneriler}

Su kefiri taneleri ile fermente edilen portakal suyu örneklerinde E. coli inaktivasyonun incelendiği bu çalışmada, 4 günlük depolama süreci boyunca $5.38 \log \mathrm{kob} / \mathrm{mL}$ inaktivasyon gerçekleştiği görülmüştür. Gerçekleşen inaktivasyonun matematiksel olarak model karşılaştırılması yapıldığında, inaktivasyonu en iyi açıklayan doğrusal modelin $0.998 \mathrm{R}^{2}$ ve $0.025 \mathrm{HKO}$ ile kübik model olduğu, doğrusal olmayan modelin ise $0.995 \mathrm{R}^{2}$ ve $0.053 \mathrm{HKO}$ ile Brody model olduğu tespit edilmiştir. İçerdiği probiyotik laktik asit bakterileri ve maya florası ile farklı meyve suları ile hazırlanan su kefiri fermente içeceği alternatif sağlıklı bir içecek olarak tüketilebilir özelliktedir. Bu çalışmada, 4 günlük depolama süreci boyunca patojen mikroorganizma inaktivasyonu incelenmiştir. Dolayısıyla depolama süresi uzatılarak, alternatif olarak farklı formülasyonlarla üretilen su kefiri 
içeceklerinin farklı patojen mikroorganizmalar üzerindeki davranışları ileriki çalışmalarda

incelenebilir.

\section{Kaynaklar}

Aslım, B., Yüksekdağ, Z. N., Sarıkaya, E., ve Beyatlı, Y., (2005). Determination of the bacteriocin-like substances produced by some lactic acid bacteria isolated from Turkish dairy products. $L W T, 38:$ 691694.

Baranyi, J., ve Roberts, T. A., (1994). A dynamic approach to predicting bacterial growth in food. Int. J. of Food Microbiol, 23 (3-4), 277-29.

Çon, A. H. ve Gökalp, H. Y., (2000). Laktik asit bakterilerinin antimikrobiyal metabolitleri ve etki şekilleri. Turk Mikrobiyol Cem Derg, 30: 180-190.

Davidović, S. Z., Miljković, M. G., Rajilić-Stojanović, M. D., Dimitrijević-Branković, S. I. Ve Antonović, D. G., (2015). Water Kefir grain as a source of potent dextran producing lactic acid bacteria, Chemical Industry/Hemijska Industrija. 69(6), 595-604.

Dinçer, E., Kıvanç, M., ve Karaca, H. (2010). Biyokoruyucu olarak laktik asit bakterileri. Glda, 35(1), 1-8.

Erginkaya, Z., Sarıkodal, E., Özkütük, S. T., Konuray, G., \& Turhan, E. Ü. (2019). Probiyotik bitter çikolata üretiminde mikroenkapsüle Lactobacıllus rhamnosus kullanımı. Gıda, 44(2), 238-247.

Evren, M., Albayram, C., ve Apan, M. (2006). Laktik asit bakterilerinin oluşturduğu antimikrobiyel maddeler. Türkiye 9. Gida Kongresi, 24-26.

FDA. (1995). Bacteriolological Analytical Manual. Food and Drug Administration 16 th Edition. AOAC Int. Gaithersburg MD.

Fels, L., Jakob, F., Vogel, R. F., ve Wefers, D. (2018). Structural characterization of the exopolysaccharides from water kefir. Carbohydrate polymers, 189, 296-303.

Gibson, A. M., Bratchell, N., ve Roberts, T. A. (1998). Predicting microbial growth: Growth responses of salmonellae in a laboratory medium as affected by $\mathrm{pH}$, sodium chloride and storage temperature. Int $J$ of Food Microbiol, 6(2), 155-178.

Gospavic, R., Kreyenschmidt, J., Bruckner, S., Popov, V., ve Haque, N. (2008). Mathematical modelling for predicting the growth of Pseudomonas spp. in poultry under variable temperature conditions. Int $J$ of Food Microbiol, 127(3), 290-297.

Gulitz, A., Stadie, J., Ehrmann, M. A., Ludwig, V. ve Vogel, R. F., (2013). Comparative phylobiomic analysis of the bacterial community of water kefir by $16 \mathrm{~S}$ rRNA gene amplicon sequencing and ARDRA analysis. J Appl Microbiol, 114, 1082-1091.

Gulitz, A., Stadie, J., Wenning, M., Ehrmann, M. A. ve Vogel, R. F., (2011). The microbial diversity of water kefir. Int J Food Microbiol, 151, 284-288.

IFST. (1993). Shelf life of food muidelines for its determination and prediction. London: Institute of Food Science and Technology.

Kalkan, S. (2016). Probiyotik laktik asit bakterilerinin Staphylococcus aureus'a karşı antimikrobiyel etkilerinin farklı matematiksel modeller ile analizi. Sinop Üniv Fen Bil De, 1(2), 150-159.

Kalkan, S. (2019). Predicting the antimicrobial effect of probiotic lactic acid bacteria against Staphylococcus aureus in white cheeses, using Fourier series modeling method. J of Food Safety, e12724.

Kalkan, S. ve Otağ, M. R., (2019). Some of the quality properties and bioactivity of orange juice fermented with water kefir microorganisms. 5th International Conference on Engineering and Natural Sciences (ICENS), 12-16 June 2019, Prague, Czech Republic. pp 31-35.

Külcü, D. B., Kalkan, S., ve Akben, S. B. (2019). Polynomial surface fitting and artificial neural networksbased analysis of the storage days and garlic extract supplementation dependent microbial growths in minced raw chicken meat. J of Food Processing and Preservation, 43(3), e13882.

Laureys, D. ve De Vuyst, L., (2014). Microbial species diversity, community dynamics, and metabolite kinetics of water kefir fermentation. Appl. Environ. Microbiol, 80(8), 2564-2572.

Laureys, D., Cnockaert, M., De Vuyst, L, ve Vandamme, P., (2016). Bifidobacterium aquikefiri sp. nov., isolated from water kefir. Int J of Systematic and Evolutionary Microbiol, 66(3), 1281-1286.

Leroi, F., Pidoux, M., (1993). Detection of interactions between yeasts and lactic acid bacteria isolated from sugary kefir grains. $J$ of Appl Microbiol, 74(1), 48-53. 
Nataro, J. P., ve Kaper, J. B. (1998). Diarrheagenic Escherichia coli. Clinical microbiology reviews, 11(1), 142-201.

Perez-Rodriguez, F., ve Valero, A. (2013). Predictive microbiology in foods (pp. 1-10). New York, NY: Springer.

Pidoux, M., 1989. The microbial flora of sugary kefir grain (the gingerbeer plant): biosynthesis of the grain from Lactobacillus hilgardii producing a polysaccharide gel. MIRCEN Journal 5, 223-238.

Raffellini, S., Guerrero, S., ve Alzamora, S. M. (2008). Effect of hydrogen peroxide concentration and pH on inactivation kinetics of Escherichia coli. J of Food Safety, 28(4), 514-533.

Sağdıç O., Küçüköner, E., ve Özçelik, S., (2004). Probiyotik ve prebiyotiklerin fonksiyonel özellikleri. Atatürk Üniv. Ziraat Fak. Derg., 35, 221-228.

Stadie, J., Gulitz, A., Ehrmann, M. A., ve Vogel, R. F. (2013). Metabolic activity and symbiotic interactions of lactic acid bacteria and yeasts isolated from water kefir. Food Microbiol, 35(2), 92-98.

Taş, E., Erginkaya, Z., Kalkan, S., Turhan, E. Ü. (2017). Determination of antimicrobial effects of probiotic lactic acid bacteria and garlic extract against some foodborn pathogenic bacteria. Turkish $J$ of Agriculture-Food Sci and Techn, 5(2), 125-131.

Temelli, S. (2002). Gıda zehirlenmesine neden olan E. coli O157: H7 ve önemi. Uludă̆ Üni Veteriner Fak Derg. 21, 133-138.

Tsujihata, S., Entani, E., Asai, M., Tsukamoto, Y., ve Ohta, M. (1998). Mathematical modeling to predict the bactericidal effect of processed vinegar on Escherichia coli O157: H7. Int J of Food Microbiol, 43(12), 135-138.

Virto, R., Sanz, D., Alvarez, I., Condon, S., ve Raso, J. (2006). Application of the Weibull model to describe inactivation of Listeria monocytogenes and Escherichia coli by citric and lactic acid at different temperatures. $J$ of the Sci of Food and Agriculture, 86(6), 865-870. 